\begin{tabular}{|ccc|}
\hline JURNALASI & Jurnal Inovasi Teknologi Pendidikan & T P \\
INOVNASI & Volume 3, No 1, April 2016 (13-24) & T \\
PENDIDIKAN & Online: http://journal.uny.ac.id/index.php/jitp & $\begin{array}{l}\text { lkatan Profesi Teknologi } \\
\text { Pendidikan Indonesia }\end{array}$ \\
\hline \hline
\end{tabular}

\title{
PERSEPSI GURU TENTANG DIGITAL NATIVES, SUMBER BELAJAR DIGITAL DAN MOTIVASI MEMANFAATKAN SUMBER BELAJAR DIGITAL
}

\author{
Ferdinandus Bate Dopo, Christina Ismaniati \\ Program Studi Teknologi Pembelajaran PPs UNY, Fakultas Ilmu Pendidikan UNY \\ ferdinbate@yahoo.com, ismaniati_fipuny@yahoo.com
}

\begin{abstract}
Abstrak
Penelitian ini bertujuan untuk mengungkapkan (1) pengaruh persepsi guru tentang digital natives terhadap motivasi guru memanfaatkan sumber belajar digital (2) pengaruh persepsi guru tentang sumber belajar digital terhadap motivasi guru memanfaatkan sumber belajar digital dan (3) pengaruh persepsi guru tentang digital natives dan persepsi guru tentang sumber belajar digital secara bersama-sama terhadap motivasi guru memanfaatkan sumber belajar digital. Penelitian ini merupakan penelitian deskriptif-korelasional dengan pendekatan kuantitatif. Populasi dan sampel dalam penelitian ini adalah guru-guru SMA Regina Pacis Bajawa, SMA Seminari Mataloko dan SMA Negeri 1 Golewa. Teknik sampel yang digunakan adalah proportional random sampling. Angket yang digunakan untuk memperoleh data disusun menggunakan skala Likert. Teknik analisis yang digunakan adalah analisis regresi dengan teknik statistik uji t dan uji F dengan taraf signifikaansi 0,05. Hasil penelitian adalah sebagai berikut: (1) Ada pengaruh yang positif dan signifikan persepsi guru tentang digital natives terhadap motivasi guru memanfaatkan sumber belajar digital. (2) Ada pengaruh yang positif dan signifikan persepsi guru tentang sumber belajar digital terhadap motivasi guru memanfaatkan sumber belajar digital. (3) Ada pengaruh yang positif dan signifikan, persepsi guru tentang digital natives dan persepsi guru tentang sumber belajar digital secara bersama-sama terhadap motivasi guru memanfaatkan sumber belajar digital.
\end{abstract}

Kata kunci: persepsi, digital natives, sumber belajar digital, motivasi

\section{TEACHER'S PERCEPTION OF DIGITAL NATIVES, DIGITAL LEARNING RESOURCES AND MOTIVATION TO UTILIZE DIGITAL LEARNING RESOURCES}

\author{
Ferdinandus Bate Dopo, Christina Ismaniati \\ Program Studi Teknologi Pembelajaran PPs UNY, Fakultas Ilmu Pendidikan UNY \\ ferdinbate@yahoo.com, ismaniati_fipuny@yahoo.com
}

Abstract

This study aims to reveal (1) the influence of teacher's perception of digital natives toward teacher's motivation to utilize digital learning resources. (2) the influence of teacher's perception of digital learning resources toward teacher's motivation to utilize digital learning resources and (3) the influence both of teacher's perception of digital natives and digital learning resources toward teacher's motivation to utilize digital learning resources. This study used the descriptive-correlational quantitative approach. The Population and sample were high school teachers of Regina Pacis Bajawa, SMA Seminari Mataloko and SMA Negeri 1 Golewa. Sampling technique in this research was proportional random sampling. A questionnaire was used to obtain the data. The data were analyzed using the Likert scale. The instrument was developed based on lattice theory of assessment instruments relevant to the study variables. The analysis technique used is a regression followed by statistic technique of $t$ test and $F$ test with the significance level of 0.05. The results are as follows. (1) There is a positive and significant influence of teacher's perception of digital natives toward teacher's motivation to utilize digital learning resources. (2) There is a positive and significant influence of teacher's perception of digital learning resources and teacher's motivation to utilize digital learning resources. (3) There is a positive and significant influence both of teacher's perception of digital learning resources and teacher's motivation to utilize digital learning resources.

Keywords: perception, digital natives, digital learning resources, motivation 


\section{Pendahuluan}

Pada hakikatnya teknologi pendidikan adalah penerapan dari ilmu atau pengetahuan yang terorganisir ke dalam tugas-tugas praktis dalam kesatuannya sebagai suatu produk dan proses untuk mengatasi masalah belajar pada manusia. Sebagai suatu produk, teknologi pendidikan mudah dipahami karena sifatnya lebih konkrit seperti radio, televisi, proyektor, OHP dan sebagainya. Sebagai sebuah proses teknologi pendidikan bersifat abstrak. Menegaskan pemahaman ini teknologi pendidikan dipahami sebagai suatu proses yang kompleks, dan terpadu yang melibatkan orang, prosedur, ide, peralatan, dan organisasi untuk menganalisis masalah, mencari jalan untuk mengatasi permasalahan, melaksanakan, menilai, dan mengelola pemecahan masalah tersebut yang mencakup semua aspek belajar manusia (AECT, 1986, p. 1).

Dewasa ini sudah menjadi lumrah siswa belajar dengan bantuan teknologi baru. Siswa bermain video games yang kompleks, bekerja dengan simulasi yang menempatkan mereka dalam situasi yang menantang dan belajar secara online. Perpustakaan online dan warung internet hampir tidak sulit untuk dijumpai yang memungkinkan siswa untuk memutuskan apa yang ingin dipelajari, kapan ingin belajar, dan bagaimana belajar itu terjadi.

Fenomena ini menggambarkan bahwa perkembangan zaman telah melahirkan manusia-manusia baru dengan kebutuhan-kebutuhan baru. Prensky (2001, p.1) seorang tokoh inovasi pendidikan menyebut generasi sekarang sebagai "digital natives", yaitu generasi yang tumbuh dan dibesarkan di tengah dunia teknologi digital. Lebih lanjut menurutnya permasalahan dalam dunia pendidikan dewasa ini merupakan implikasi langsung dari fenomena tersebut. Oleh karenanya membelajarkan digital natives membutuhkan sebuah pendekatan yang berbeda. Terhadap fenomena ini teknologi pendidikan dituntut untuk melakukan pengkajian diri (Seel \& Richey, 1994, p. 1; Reiser \& Ely, 1997, p. 71).
Pengkajian diri mensyaratkan bahwa teknologi pendidikan dapat memfasilitasi kebutuhan-kebutuhan baru dan siap untuk melakukan peran baru. Dengan dasar pemahaman seperti ini, teknologi pendidikan hendaknya dipahami juga sebagai: "Kombinasi proses dan alat untuk mengatasi masalah-masalah belajar dengan menekankan pada penerapan peralatan terkini, komputer dan teknologi-teknologi yang terkait" (Roblyer, 2003, p. 6). Dengan demikian dalam konteks zaman ini, teknologi pendidikan dapat diasumsikan sebagai praktik memanfaatkan teknologi untuk mengatasi masalah belajar dan memfasilitasi pembelajaran serta meningkatkan kinerja dengan menerapkan proses dan produk teknologi terkini dengan tepat.

Sebagai aplikasi praktis teknologi pendidikan, sumber belajar memainkan peran krusial dalam mengatasi masalahmasalah belajar. Kemajuan teknologi telah melahirkan sumber-sumber belajar baru. Digitalisasi menjadi karakter pembeda sumber-sumber tersebut. Digital merujuk pada gabungan elemen perangkat keras (pemrosesan, memori, input dan komunikasi) dan perangkat lunak (sistem operasi dan program aplikasi) untuk melakukan berbagai tugas. Dengan demikian sumber belajar digital dipahami sebagai gabungan elemen perangkat keras dan lunak yang mempunyai potensi untuk mengatasi $\mathrm{m}$ asalah belajar dan memfasilitasi kegiatan belajar (OECD, 2009, p. 31).

Ketersediaan yang luas sumber belajar berbasis teknologi dalam berbagai format menawarkan kemungkinan untuk membuat perbedaan yang mendalam di bidang pendidikan (Hill \& Hannafin, 2001, p. 37). Menegaskan hal ini Resnick (2002, p. 33) menyatakan tak hanya mentransmisi dan mengakses informasi, sumber-sumber belajar digital seperti komputer dapat dipandang sebagai material konstruksi yang menyediakan kesempatan yang luas dimana orang dapat berkreasi dan berekspresi. Lebih lanjut, dengan kemampuan untuk visualisasi, simulasi, games dan interaktivitas, penggunaan sumber belajar digital 
telah membawa dampak bagi peningkatan kualitas pembelajaran terkait dengan motivasi, retensi, gaya belajar dan kreativitas (BECTA, 2007, pp. 9-10).

Menghadapi perubahan dengan segala implikasinya, beberapa sekolah di kabupataen Ngada, Nusa Tenggara Timur mulai giat membangun. Dalam beberapa tahun terakhir salah satu upaya nyata yang telah dilaksanakan oleh sekolah-sekolah tersebut adalah mendistribusikan sumbersumber belajar digital untuk menyediakan peluang belajar bagi siswa dan memfasilitasi kegiatan belajar mereka seperti perpustakaan, laboratorium bahasa, laboratorium komputer, yang didukung dengan peralatan dan multimedia berbasis teknologi digital. Menindaklanjuti ketersediaan sumbersumber belajar yang ada, sekolah telah mulai menyarankan, mendorong dan menuntut guru dan siswa untuk menggunakan dan memanfaatkan sumber-sumber belajar tersebut dalam pembelajaran.

Namun demikian usaha pengadaan dan distribusi sumber-sumber belajar digital yang sudah dan sedang gencar digalakkan yang lahir dari potensi besar sumbersumber belajar digital, rupanya belum menuai hasil yang diharapkan. Kenyataan menunjukkan sumber-sumber tersebut belum dimanfaatkan secara umum dan luas baik dikalangan guru maupun para siswa. Banyak guru masih menggunakan pendekatan tradisional dalam membelajarkan siswa. Guru masih menjadi satu-satunya sumber belajar, akibatnya pemanfaatan sumber-sumber belajar digital dalam pembelajaran menjadi sangat terbatas.

Kenyataan lain menunjukkan, ketika guru dan siswa diperkenalkan dengan sumber belajar digital secara umum kepada mereka diajarkan bagaimana mengoperasikan sumber-sumber digital tersebut. Selanjutnya kemampuan ini diaplikasikan masih terbatas untuk tugas administratif sekolah seperti menggunakan komputer untuk mempersiapkan silabus dan rencana pelaksanaan pembelajaran (RPP), membuat dokumentasi penilaian dan membuat soal-soal evaluasi. Demikian juga siswa menggunakan sumber belajar digital hanya untuk memenuhi tuntutan kurikulum pendidikan TIK, seperti mampu mengoperasikan komputer atau sekedar mencari informasi di internet.

Dalam situasi di mana adopsi inovasi pendidikan adalah hal yang diinginkan, konsep agen perubahan menjadi relevan. Agen perubahan adalah individu yang mampu memfasiltasi lahirnya inovasi-inovasi baru yang potensial bagi peningkatan kualitas pendidikan. Dengan demikian teknologi pendidikan tidak dan tidak akan pernah transformatif tanpa hadirnya agen-agen perubahan yang dapat mengintegrasikan teknologi ke dalam kurikulum dan menggunakannya untuk meningkatkan pembelajaran siswa.

Banyak faktor yang mempengaruhi kecilnya pemanfaatan teknologi dalam proses pembelajaran diantaranya komputer self-efficacy, pengalaman mengajar, dukungan teknologi komputer, praktek pedagogis guru dan pengembangan profesional dalam mengintegrasikan teknologi (Gilakjani, 2013, pp. 262-264; Bingimlas, 2009, p. 243). Hasil penelitian tersebut menyarankan bahwa perubahan positif dapat dibuat dalam proses pendidikan bagi guru untuk menggunakan teknologi.

Demikian dapat dikatakan bahwa banyak penelitian yang berhubungan dengan teknologi dalam pendidikan telah sangat terfokus pada bagaimana mendorong para guru untuk menjadi profesional mengintegrasikan teknologi dalam kurikulum, dengan kurang memperhatikan faktor-faktor yang secara fundamental mempengaruhi guru memanfaatkan sumber belajar digital dalam pembelajaran. Dengan dasar pemahaman demikian adalah bijaksana untuk pertama-tama mempertim-bangkan faktor yang mempengaruhi keputusan guru untuk memanfaatkann teknologi sebelum membahas berbagai aplikasi pembelajaran untuk membantu mereka dalam memajukan dan memaksimalkan efektivitas teknologi.

Motivasi guru memainkan peran penting dalam keseluruhan proses pen- 
didikan. Voluntary Service Overseas (VSO, 2002, pp. 21-22) dalam laporan penelitian terhadap guru-guru di negara berkembang mencatat bahwa, ada hubungan yang kuat antara motivasi, kinerja guru dan peningkatan kualitas pendidikan. Namun demikian, walupun motivasi guru merupakan hal yang fundamental dalam proses pembelajaran, meningkatkan motivasi guru belum secara menyeluruh menjadi prioritas utama. Asumsi yang bisa dibangun adalah telah terjadi krisis keseimbangan dengan mengesampingkan motivasi. Secara umum kurangnya motivasi pada guru termanifestasi dalam keengganan guru untuk berpartisipasi dalam kegiatan sekolah, kehadiran yang kurang, tidak kreatif dalam pembelajaran, kurangnya minat untuk berinovasi. Dengan demikian dengan tidak memanfaatkan sumber-sumber belajar digital telah mengindikasikan bahwa masih banyak guru yang belum memiliki motivasi yang tinggi.

Kurangnya motivasi dianggap ditentukan oleh faktor-faktor yang berbeda. Huitt (2011,p.2) secara umum mengklasifikasikan faktor-faktor yang mempengaruhi motivasi dalam dua kategori yang berbeda yaitu faktor ekstrinsik sebagai faktor yang ada diluar diri individu dan faktor instrinsik yang muncul dari dalam diri individu yang meliputi aspek kognitif, afeksi dan konatif. Sebagai komponen kognitif, persepsi memiliki peran penting dalam pembentukan kognisi yang terkait dengan pengetahuan manusia.

Menempatkan persepsi dalam kajian penelitian ini didasari gagasan bahwa salah satu faktor keberhasilan yang tidak bisa diabaikan guru dalam membelajarkan siswa adalah pengetahuan tentang siswa dan karakter yang mereka miliki (Shulman, 1987, p. 8). Oleh karena itu, pendidikan hari ini harus dibangun atas dasar bahwa siswa hari ini berbeda dari pendahulu mereka. Siswa hari ini adalah digital natives, mereka adalah produk dunia digital. Simulasi, gaming, interaktifitas adalah hal yang dilakukan dan ingin dilakukan siswa hari ini. Digital natives, sebagai agen buda- ya membawa habitus mereka ke dalam dunia akademik.

Karena itu, sangat penting bahwa sebelum melakukan reformasi pendidikan, motivasi dan persepsi guru dieksplorasi, diidentifikasi dan ditangani untuk menentukan kebijakan-kebijakan demi meraih tujuan yang ingin dicapai. Asumsi yang bisa dibangun adalah dengan memahami secara baik siapa siswa mereka dan bahwa bagaimana dan dengan apa mereka belajar dapat mendorong guru untuk memanfaatkan sumber belajar digital.

Dengan landasan pemikiran demikian maka penelitian ini fokus pada penyelidikan tentang pengaruh persepsi guru tentang digital natives dan sumber belajar digital terhadap motivasi guru memanfaatkan sumber belajar digital.

Berdasarkan latar belakang masalah, maka rumusan masalah yang dapat dikemukakan dalam penelitian ini yaitu: Adakah pengaruh persepsi guru tentang digital natives terhadap motivasi guru memanfaatkan sumber belajar digital? Adakah pengaruh persepi guru tentang sumber belajar digital terhadap motivasi guru memanfaatkan sumber belajar digital? Adakah pegaruh secara bersama-sama persepsi guru tentang digital natives dan persepsi guru tentang sumber belajar digital terhadap motivasi guru memanfaatkan sumber belajar digital?

Sedangkan tujuan dari penelitian ini yaitu ingin mengungkapkan pengaruh persepsi guru tentang digital natives terhadap motivasi guru memanfaatkan sumber belajar digital, pengaruh persepsi guru tentang sumber belajar digital terhadap motivasi guru memanfaatkan sumber belajar digital dan pengaruh persepsi guru tentang digital natives dan persepsi guru tentang sumber belajar digital secara bersama-sama terhadap motivasi guru memanfaatkan sumber belajar digital.

\section{Metode Penelitian}

Penelitian ini merupakan penelitian deskriptif-korelasional dengan pendekatan 
kuantitatif. Penelitian ini bertujuan untuk mengetahui nilai mandiri tiap-tiap variabel serta pengaruh variabel bebas terhadap variabel terikat. Dalam penelitian ini pengaruh variabel bebas terhadap variabel terikat lebih bersifat hubungan sebab akibat atau kausalitas. Data dalam penelitian ini dikonversikan dalam bentuk angka dan dianalisis menggunakan statistik.

Penelitian dilaksanakan di SMA Regina Pacis Bajawa, SMA Seminari Mataloko dan SMA Negeri I Golewa di kabupaten Ngada, Nusa Tengara Timur Pengambilan data penelitian dilakukan pada bulan Agustus 2014. Populasi dalam penelitian ini adalah semua guru SMA Regina Pacis Bajawa, SMA Seminari Mataloko dan SMA Negeri 1 Golewa yang berjumlah 104 orang dengan sampel 68 orang. Teknik sampel yang digunakan dalam penelitian ini adalah proportional random sampling.

Pengumpulan data untuk penelitian ini menggunakan teknik angket. Angket dalam penelitian ini merupakan angket tertutup, menggunakan pernyataan dengan jawaban yang telah disediakan. Kegiatan yang dilakukan adalah menjelaskan kepada para guru tujuan dilakukannya penelitian ini, serta cara pengisian angket. Kemudian selanjutnya membagikan angket untuk diisi oleh guru lalu mengumpulkannya untuk dianalisis.

Berdasarkan jumlah variabel penelitian, nstrumen pengumpulan data terdiri atas: (a) angket persepsi guru tentang digital natives; (b) angket persepsi guru tentang sumber belajar digital; (c) angket motivasi guru memanfaatkan sumber-sumber belajar digital. Dalam penelitian ini, data dianalisis mengunakan skala Likert (1932, p.14). Variabel yang akan diukur dijabarkan menjadi indikator variabel. Kemudian indikator tersebut dijadikan sebagai titik tolak menyusun butir-butir instrumen yang berupa pernyataan yang perlu dijawab oleh responden. Jawaban setiap butir instrumen mempunyai gradasi dari sangat positif sampai sangat negatif dengan menggunakan skala lima (lima pilihan) sebagai berikut: sangat setuju (SS), setuju
(S), cukup (C), tidak setuju (TS), dan sangat tidak setuju (STS) dengan bobot masingmasing 5, 4, 3, 2 dan 1 . Pengembangan instrumen didasarkan pada kisi-kisi instrumen yang merupakan kajian teori yang relevan dengan varibel penelitian.

Analisis data dimaksudkan untuk membuktikan hipotesis. Untuk sampai pada pembuktian tersebut terlebih dahulu akan dilakukan deskripsi hasil penelitian dan uji asumsi yang diperlukan sebelum melakukan uji hipotesis. Analisis deskriptif digunakan untuk mengetahui gambaran persepsi guru tentang digital natives, persepsi guru tentang sumber belajar digital dan motivasi guru memanfaatkan sumber belajar digital berdasarkan distribusi frekuensi jawaban responden atas pernyataan-pernyataan dalam kuesioner. Item-item pernyataan dalam

Variabel-variabel tersebut secara keseluruhan digambarkan dalam bentuk tabel deskripsi frekuensi dengan kategori penilaian sebagai berikut.

Tabel 1. Kategori Persentase

\begin{tabular}{ll}
\hline Kategori & Persentase \\
\hline Baik & $76 \%-100 \%$ \\
Cukup & $56 \%-75 \%$ \\
Kurang Baik & $40 \%-55 \%$ \\
Tidak Baik & Kurang dari 40\% \\
\hline
\end{tabular}

Oleh karena parameter dari suatu hubungan fungsional antara variabel terikat dengan lebih dari satu variabel bebas ingin diestimasikan, maka analisis data yang digunakan dalam penelitian ini adalah analisis regresi berganda (multiple regression) dengan persamaan $Y=\alpha+\beta_{1} X_{1}+$ $\beta_{2} X_{2}+\varepsilon$. Untuk mengungkapkan pengaruh variabel bebas terhadap variabel terikat baik secara parsial maupun simultan akan dilakukan uji $\mathrm{t}$ dan uji $\mathrm{F}$ dengan asumsi bahwa uji prsyarat analisis yang dubutuhkan dalam analisis regresi linear telah memenuhi persyaratan dari aspek normalitas, linearitas, multikolinearitas dan heterokedastisitas. 


\section{Hasil Penelitian dan Pembahasan}

Hasil Penelitian

Instrumen persepsi guru tentang digital natives $\left(\mathrm{X}_{1}\right)$ persepsi guru tentang sumber belajar digital $\left(X_{2}\right)$ dan motivasi guru memanfaatkan sumber belajar digital (Y) didasarkan pada skala Likert dengan skoring 5 untuk pernyataan sangat setuju, 4 setuju, 3 ragu-ragu, 2 tidak setuju, dan 1 untuk pernyataan sangat tidak setuju. Rekapitulasi distribusi frekuensi tanggapan responden terhadap item-item pernyataan variabel-variabel tersebut adalah sebagai berikut.

Dalam Tabel 2 dideskripsikan bahwa tanggapan responden terhadap itemitem variabel persepsi guru tentang digital natives adalah sebagai berikut: Secara umum variabel persepsi guru tentang digital natives termasuk dalam kategori baik dengan rata-rata skor total 263 dengan persentase $77,35 \%$. Berdasarkan hasil perhitungan, tanggapan responden terhadap variabel persepsi guru tentang digital natives yang paling tinggi ada pada butir nomor (9) yaitu siswa belajar lebih cepat melalui multimedia (gambar, suara dan video) daripada hanya melalui teks dan tanggapan responden terhadap variabel persepsi guru tentang digital natives yang paling rendah ada pada butir nomor (13) yaitu siswa bergantung pada ruang online untuk menemukan informasi yang mereka butuhkan.

Pada Tabel 3 dijelaskan bahwa tanggapan responden terhadap item-item variabel persepsi guru tentang sumber belajar digital adalah sebagai berikut: Secara umum variabel persepsi guru tentang sumber belajar digital termasuk dalam kategori baik dengan rata-rata skor total 300, dengan persentase $88,23 \%$. Berdasarkan hasil perhitungan, tanggapan responden terhadap variabel persepsi guru tentang sumber belajar digital yang paling tinggi ada pada butir nomor (4) yaitu memungkinkan akses terhadap informasi terkini dan tanggapan responden terhadap variabel persepsi guru tentang sumber belajar digital yang paling rendah ada pada butir nomor (8) yaitu memungkinkan interaksi yang bebas dan terbuka dengan pengguna.

Tabel 2. Deskripsi Tanggapan Responden terhadap Variabel Persepsi Guru tentang Digital Natives $\left(\mathrm{X}_{1}\right)$

\begin{tabular}{|c|c|c|c|c|c|c|c|c|c|c|c|c|c|c|}
\hline \multirow[b]{3}{*}{ No } & \multicolumn{14}{|c|}{ Tanggapan Responden } \\
\hline & & \multicolumn{2}{|c|}{ SS (5) } & \multicolumn{2}{|c|}{ S (4) } & \multicolumn{2}{|c|}{$C(3)$} & \multicolumn{2}{|c|}{ TS (2) } & \multicolumn{2}{|c|}{ STS (1) } & \multirow[b]{2}{*}{$\mathrm{N}$} & \multirow[b]{2}{*}{ Skor } & \multirow[b]{2}{*}{ Kategori } \\
\hline & Item & $\mathrm{f}$ & $\%$ & $\mathrm{f}$ & $\%$ & $\mathrm{f}$ & $\%$ & $\mathrm{f}$ & $\%$ & $\mathrm{f}$ & $\%$ & & & \\
\hline 1 & item 1 & 13 & 19,1 & 38 & 55,9 & 15 & 22,1 & 2 & 2,9 & 0 & 0 & 68 & 266 & Baik \\
\hline 2 & item 2 & 10 & 14,7 & 31 & 45,6 & 24 & 35,3 & 3 & 4,4 & 0 & 0 & 68 & 252 & Cukup \\
\hline 3 & item 3 & 28 & 41,2 & 28 & 41,2 & 10 & 14,7 & 1 & 1,5 & 0 & 0 & 68 & 284 & Baik \\
\hline 4 & item 4 & 9 & 13,2 & 43 & 63,2 & 10 & 14,7 & 5 & 7,4 & 0 & 0 & 68 & 257 & Cukup \\
\hline 5 & item 5 & 13 & 9,1 & 38 & 55,9 & 15 & 22,1 & 2 & 2,9 & 0 & 0 & 68 & 266 & Baik \\
\hline 6 & item 6 & 11 & 16,2 & 27 & 3,7 & 25 & 36,8 & 4 & 5,9 & 0 & 0 & 68 & 246 & Cukup \\
\hline 7 & item 7 & 16 & 23,5 & 32 & 47,1 & 16 & 23,5 & 4 & 5,9 & 0 & 0 & 68 & 260 & Baik \\
\hline 8 & item 8 & 20 & 29,4 & 24 & 50,0 & 13 & 19,1 & 1 & 1,5 & 0 & 0 & 68 & 277 & Baik \\
\hline 9 & item 9 & 39 & 57,4 & 21 & 30,9 & 8 & 11,8 & 0 & 0 & 0 & 0 & 68 & 303 & Baik \\
\hline 10 & item 10 & 15 & 22,1 & 31 & 45,6 & 20 & 29,4 & 2 & 2,9 & 0 & 0 & 68 & 263 & Baik \\
\hline 11 & item 11 & 21 & 30,9 & 37 & 54,4 & 9 & 13,2 & 1 & 1,5 & 0 & 0 & 68 & 282 & Baik \\
\hline 12 & item 12 & 17 & 25,0 & 33 & 48,5 & 10 & 14,7 & 7 & 10,3 & 0 & 0 & 68 & 261 & Baik \\
\hline \multirow[t]{3}{*}{13} & item 13 & 2 & 2,9 & 26 & 38,2 & 29 & 42,6 & 6 & 8,8 & 0 & 0 & 68 & 213 & $\begin{array}{c}\text { Kurang } \\
\text { Baik }\end{array}$ \\
\hline & & \multirow{2}{*}{\multicolumn{10}{|c|}{$\begin{array}{l}\text { Skor nilai variabel persepsi guru tentang digital natives } \\
\text { Rata-rata variabel persepsi guru tentang digital natives }\end{array}$}} & & 3430 & \\
\hline & & & & & & & & & & & & & 263 & Baik \\
\hline
\end{tabular}


Tabel 3. Deskripsi Tanggapan Responden terhadap Variabel Persepsi Guru tentang Sumber Belajar Digital $\left(\mathrm{X}_{2}\right)$

\begin{tabular}{|c|c|c|c|c|c|c|c|c|c|c|c|c|c|c|}
\hline \multirow[b]{3}{*}{ No } & \multicolumn{14}{|c|}{ Tanggapan Responden } \\
\hline & & \multicolumn{2}{|c|}{ SS (5) } & \multicolumn{2}{|c|}{ S (4) } & \multicolumn{2}{|c|}{ C (3) } & \multicolumn{2}{|c|}{ TS (2) } & \multicolumn{2}{|c|}{ STS (1) } & \multirow[b]{2}{*}{$\mathrm{N}$} & \multirow[b]{2}{*}{ Skor } & \multirow[b]{2}{*}{ Kategori } \\
\hline & Item & $\mathrm{f}$ & $\%$ & $\mathrm{f}$ & $\%$ & $\mathrm{f}$ & $\%$ & $\mathrm{f}$ & $\%$ & $\mathrm{f}$ & $\%$ & & & \\
\hline 1 & item 1 & 28 & 41,2 & 39 & 50,0 & 5 & 7,4 & 1 & 1,5 & 0 & 0 & 68 & 293 & Baik \\
\hline 2 & item 2 & 33 & 48,5 & 29 & 42,6 & 5 & 7,4 & 1 & 1,5 & 0 & 0 & 68 & 298 & Baik \\
\hline 3 & item 3 & 36 & 52,9 & 27 & 39,7 & 3 & 4,4 & 2 & 2,9 & 0 & 0 & 68 & 301 & Baik \\
\hline 4 & item 4 & 44 & 64,7 & 21 & 30,9 & 3 & 4,4 & 0 & 0 & 0 & 0 & 68 & 308 & Baik \\
\hline 5 & item 5 & 35 & 51,5 & 31 & 45,6 & 2 & 2,9 & 0 & 0 & 0 & 0 & 68 & 305 & Baik \\
\hline 6 & item 6 & 34 & 50,0 & 29 & 42,6 & 5 & 7,4 & 0 & 0 & 0 & 0 & 68 & 301 & Baik \\
\hline 7 & item 7 & 37 & 54,4 & 30 & 44,1 & 1 & 1,5 & 0 & 0 & 0 & 0 & 68 & 308 & Baik \\
\hline 8 & item 8 & 27 & 39,7 & 28 & 41,2 & 12 & 17,6 & 1 & 1,5 & 0 & 0 & 68 & 285 & Baik \\
\hline 9 & item 9 & 35 & 51,5 & 30 & 44,1 & 3 & 4,4 & 0 & 0 & 0 & 0 & 68 & 304 & Baik \\
\hline \multicolumn{12}{|c|}{ Skor nilai variabel persepsi guru tentang sumber belajar digital } & \multicolumn{3}{|c|}{2703} \\
\hline \multicolumn{13}{|c|}{ Rata-rata variabel persepsi guru tentang sumber belajar digital } & 300 & Baik \\
\hline
\end{tabular}

Tabel 4. Deskripsi Tanggapan Responden terhadap Variabel Motivasi Guru Memanfaatkan Sumber Belajar Digital (Y)

\begin{tabular}{|c|c|c|c|c|c|c|c|c|c|c|c|c|c|c|}
\hline \multirow[b]{3}{*}{ No } & \multicolumn{14}{|c|}{ Tanggapan Responden } \\
\hline & & \multicolumn{2}{|c|}{ SS (5) } & \multicolumn{2}{|c|}{ S (4) } & \multicolumn{2}{|c|}{ C (3) } & \multicolumn{2}{|c|}{ TS (2) } & \multicolumn{2}{|c|}{ STS (1) } & \multirow[b]{2}{*}{$\mathrm{N}$} & \multirow[b]{2}{*}{ Skor } & \multirow[b]{2}{*}{ Kategori } \\
\hline & Item & $\mathrm{f}$ & $\%$ & $\mathrm{f}$ & $\%$ & $\mathrm{f}$ & $\%$ & $\mathrm{f}$ & $\%$ & $\mathrm{f}$ & $\%$ & & & \\
\hline 1 & item 1 & 28 & 41,2 & 31 & 45,6 & 6 & 8,8 & 2 & 2,9 & 1 & 1,5 & 68 & 287 & Baik \\
\hline 2 & item 2 & 16 & 23,5 & 27 & 39,7 & 18 & 26,5 & 4 & 5,9 & 3 & 4,4 & 68 & 253 & Cukup \\
\hline 3 & item 3 & 21 & 30,9 & 36 & 52,9 & 10 & 14,7 & 1 & 1,5 & 0 & 0 & 68 & 281 & Baik \\
\hline 4 & item 4 & 27 & 39,7 & 29 & 42,6 & 10 & 14,7 & 2 & 2,9 & 0 & 0 & 68 & 285 & Baik \\
\hline 5 & item 5 & 26 & 38,2 & 29 & 42,6 & 11 & 16,2 & 2 & 2,9 & 0 & 0 & 68 & 285 & Baik \\
\hline 6 & item 6 & 17 & 25,0 & 37 & 5,4 & 12 & 17,6 & 2 & 2,9 & 00 & 0 & 68 & 273 & Baik \\
\hline 7 & item 7 & 29 & 42,6 & 36 & 52,9 & 2 & 2,9 & 0 & 0 & 1 & 1,5 & 68 & 296 & Baik \\
\hline 8 & item 8 & 29 & 42,6 & 31 & 45,6 & 7 & 10,3 & 1 & 1,5 & 0 & 0 & 68 & 292 & Baik \\
\hline 9 & item 9 & 24 & 35,3 & 31 & 45,6 & 12 & 17,6 & 1 & 1,5 & 0 & 0 & 68 & 282 & Baik \\
\hline 10 & item 10 & 31 & 45,6 & 29 & 42,6 & 6 & 8,8 & 2 & 2,9 & 0 & 0 & 68 & 293 & Baik \\
\hline 11 & item 11 & 36 & 52,9 & 22 & 32,4 & 10 & 14,7 & 0 & 0 & 0 & 0 & 68 & 298 & Baik \\
\hline 12 & item 12 & 29 & 42,6 & 28 & 41,2 & 10 & 14,7 & 1 & 1,5 & 0 & 0 & 68 & 289 & Baik \\
\hline 13 & item 13 & 24 & 35,3 & 30 & 44,1 & 13 & 19,1 & 0 & 0 & 1 & 1,5 & 68 & 280 & Baik \\
\hline 14 & item 14 & 36 & 52,9 & 21 & 30,9 & 10 & 14,7 & 1 & 1,5 & 0 & 0 & 68 & 296 & Baik \\
\hline 15 & item 15 & 32 & 47,1 & 25 & 36,5 & 10 & 14,7 & 1 & 1,5 & 0 & 0 & 68 & 292 & Baik \\
\hline 16 & item 16 & 35 & 51,5 & 25 & 36,5 & 5 & 7,4 & 3 & 4,4 & 0 & 0 & 68 & 298 & Baik \\
\hline 17 & item 17 & 16 & 23,5 & 31 & 45,6 & 17 & 25,0 & 3 & 4,4 & 1 & 1,5 & 68 & 262 & Baik \\
\hline 18 & item 18 & 30 & 44,1 & 30 & 44,1 & 7 & 10,3 & 0 & 0 & 1 & 1,5 & 68 & 292 & Baik \\
\hline 19 & item 19 & 21 & 30,9 & 34 & 50,0 & 11 & 16,2 & 2 & 2,9 & 0 & 0 & 68 & 278 & Baik \\
\hline 20 & item 20 & 14 & 20,6 & 34 & 50,0 & 16 & 23,5 & 4 & 5,9 & 0 & 0 & 68 & 262 & Baik \\
\hline 21 & item 21 & 12 & 17,6 & 32 & 47,1 & 22 & 32,4 & 2 & 2,9 & 0 & 0 & 68 & 262 & Baik \\
\hline \multicolumn{12}{|c|}{ Skor nilai variabel persepsi guru tentang sumber belajar digital } & \multicolumn{3}{|c|}{5934} \\
\hline \multicolumn{13}{|c|}{ Rata-rata variabel persepsi guru tentang sumber belajar digital } & 282 & Baik \\
\hline
\end{tabular}

Tabel 4 menjelaskan bahwa tanggapan responden terhadap item-item variabel motivasi guru yang memanfaatkan sumber belajar digital adalah sebagai berikut: Secara umum variabel motivasi guru memanfaatkan sumber belajar digital ter- masuk dalam kategori baik dengan ratarata skor total 282 , dengan persentase 82 , $94 \%$. Berdasarkan hasil perhitungan, tanggapan responden terhadap variabel motivasi guru memanfatkan sumber belajar digital yang paling tinggi ada pada butir 
nomor (11) yaitu sumber belajar digital memungkinkan siswa untuk berekspresi dan berkreasi dan (16) sumber belajar digital memberikan saya kesempatan untuk menjadi fasilitator bukan penyedia informasi semata. Sedangkan tanggapan responden terhadap variabel motivasi guru memanfaatkan sumber belajar digital yang paling rendah ada pada butir nomor (2) yaitu sumber belajar digital tidak mengakibatkan siswa mengesampingkan sumber belajar tradisional (misalnya, buku perpustakaan).

Hasil uji normalitas seluruh variabel menunjukkan bahwa Asymp Sig untuk seluruh variabel memiliki nilai yang lebih besar dari taraf signifikansi sebesar 0,05. Variabel persepsi guru tentang siswa digital natives memiliki nilai Asymp Sig sebesar 0, 537 variabel persepsi guru tentang sumber belajar digital memiliki nilai Asymp Sig sebesar 0,388 dan variabel motivasi guru memanfaatkan sumber belajar digital memiliki nilai Asymp Sig sebesar 0,817. Dengan demikian dapat disimpulkan bahwa data dalam penelitian ini berdistribusi normal.

Hasil uji linearitas $X_{1}$ terhadap $Y$ diperoleh nilai signifikansi $=0,062>0,05$, maka dapat disimpulkan $\mathrm{X}_{1}$ terhadap $\mathrm{Y}$ Linear. Hasil uji linearitas $X_{2}$ terhadap $Y$ diperoleh nilai signifikansi $=0,606>0,05$, maka dapat disimpulkan $X_{2}$ terhadap $Y$ Linear.

Hasil uji multikolinearitas menunjukkan bahwa tidak terjadi multikolinearitas antar variabel bebas dalam model regresi karena nilai tolerance $>0.1$ dan nilai $\mathrm{VIF}<10$.

Hasil uji Heterokedastisitas menunjukkan tidak terjadi masalah heteroskedas- tisitas pada model regresi karena nilai signifikansi variabel persepsi guru tentang digital natives adalah 0,059>0,05. Demikian pula tidak terjadi masalah heteroskedastisitas pada model regresi karena nilai signifikansi variabel persepsi guru tentang sumber belajar digital adalah 0,443>0,05.

Untuk menguji hipotesis dalam penelitian ini ditempuh dengan pertamatama mencari model persamaan regresi linear berganda dari masalah yang diteliti. Analisis regresi bertujuan untuk mengetahui hubungan antara variabel bebas dan variabel terikat. Hasil output SPSS analisis regresi linear berganda adalah sebagai berikut.

Tabel 5. Model Summary

\begin{tabular}{|l|r|r|r|r|}
\hline & & & Adjusted & $\begin{array}{c}\text { Std. Error } \\
\text { of the } \\
\text { Model }\end{array}$ \\
\hline 1 & R & R Square & R Square & Estimate \\
\hline
\end{tabular}

Predictors: (Constant), Persepsi Guru tentang

Sumber Belajar Digital, Persepsi Guru tentang Digital Natives

Tabel 6. Anova

\begin{tabular}{|c|c|c|c|c|c|}
\hline Model & $\begin{array}{l}\text { Sum of } \\
\text { Squares }\end{array}$ & df & $\begin{array}{l}\text { Mean } \\
\text { Square }\end{array}$ & $\mathrm{F}$ & Sig. \\
\hline 1 Regression & 3829.217 & 2 & 1914.609 & 35.348 & .000 \\
\hline Residual & 3520.665 & 65 & 54.164 & & \\
\hline Total & 7349.882 & 67 & & & \\
\hline
\end{tabular}

a. Predictors: (Constant), Persepsi Guru tentang Sumber Belajar Digital, Persepsi Guru tentang Digital Natives

b. Dependent Variable: Motivasi Guru Memanfaatkan Sumber Belajar Digital

Tabel 7. Coefficientsa

\begin{tabular}{|c|c|c|c|c|c|}
\hline \multirow[b]{2}{*}{ Model } & \multicolumn{2}{|c|}{$\begin{array}{l}\text { Unstandardized } \\
\text { Coefficients }\end{array}$} & \multirow{2}{*}{$\begin{array}{c}\text { Standardized } \\
\text { Coefficients } \\
\text { Beta }\end{array}$} & \multirow[b]{2}{*}{$\mathrm{t}$} & \multirow[b]{2}{*}{ Sig. } \\
\hline & B & Std. Error & & & \\
\hline 1 (Constant) & 5.520 & 9.868 & & .559 & .578 \\
\hline Persepsi Guru tentang Digital Natives & .764 & .165 & .440 & 4.631 & .000 \\
\hline Persepsi Guru tentang Sumber Belajar Digital & 1.079 & .249 & .413 & 4.343 & .000 \\
\hline
\end{tabular}

a. Dependent Variable: Motivasi Guru Memanfaatkan Sumber Belajar Digital 
Berdasarkan Tabel 7, persamaan regresi yang dibentuk adalah: $\mathbf{Y}=5,520+$ $0,764+1,079+$ e. Persamaan regresi tersebut memberikan gambaran bahwa:

Variabel persepsi guru tentang digital natives $\left(\mathrm{X}_{1}\right)$ mempunyai nilai koefisien regresi sebesar 0,764 yang berarti persepsi guru tentang digital natives $\left(\mathrm{X}_{1}\right)$ mempunyai pengaruh yang positif terhadap motivasi guru memanfaatkan sumber belajar digital (Y). Jika persepsi guru tentang digital natives baik maka akan meningkatkan motivasi guru untuk memanfaatkan sumber belajar digital atau sebaliknya.

Variabel persepsi guru tentang sumber belajar digital $\left(\mathrm{X}_{2}\right)$ mempunyai nilai koefisien regresi sebesar 1, 079 yang berarti persepsi guru tentang sumber belajar digital $\left(X_{2}\right)$ mempunyai pengaruh yang positif terhadap motivasi guru memanfaatkan sumber belajar digital (Y). Jika persepsi guru tentang sumber belajar digital baik maka akan meningkatkan motivasi guru untuk memanfaatkan sumber belajar digital atau sebaliknya.

Konstanta mempunyai nilai 5, 520 yang artinya jika variabel $\mathrm{X} 1, \mathrm{X} 2$, mempunyai nilai nol atau tidak ada maka motivasi guru memanfaatkan sumber belajar digital sebesar 5, 520 dan nilai tersebut merupakan pengaruh dari variabel lain (e).

Nilai koefisien regresi dan model regresi linier tersebut belum dapat digunakan, baik sebagai alat pengambilan keputusan maupun alat peramalan, sebelum dilakukan uji hipotesis. Uji hipotesis akan dilakukan dengan uji $t$ untuk menguji signifikansi konstanta dari setiap variabel bebas terhadap variabel terikat dan uji $\mathrm{F}$ untuk menguji secara bersama-sama signifikansi konstanta variabel bebas terhadap variabel terikat.

\section{Uji Hipotesis Parsial (Uji t)}

Hipotesis yang dibangun adalah sebagai berikut:

\section{Hipotesis Pertama:}

Ho1: Tidak ada pengaruh yang signifikan persepsi guru tentang digital natives terhadap motivasi guru memanfaatkan sumber belajar digital.

$\mathrm{Ha}_{1}$ : Ada pengaruh yang signifikan persepsi guru tentang digital natives terhadap motivasi guru memanfaatkan sumber belajar digital. Pengambilan keputusan berdasarkan probabilitas adalah sebagai berikut: Jika Sig. > 0,05 maka Ho diterima Jika Sig. < 0,05 maka Ha ditolak, Ha diterima

Terlihat bahwa pada kolom Sig. untuk variabel persepsi guru tentang digital natives $\left(\mathrm{X}_{1}\right)=0,000$ mempunyai angka signifikansi $<0,05$, dengan demikian Ha diterima atau dengan kata lain variabel persepsi guru tentang digital natives $\left(\mathrm{X}_{1}\right)$ signifikan mempengaruhi motivasi guru memanfaatkan sumber belajar digital.

Hipotesis Kedua:

$\mathrm{Ho}_{2}$ : Tidak ada pengaruh yang signifikan persepsi guru tentang sumber belajar digital terhadap motivasi guru memanfaatkan sumber belajar digital.

$\mathrm{Ha}_{2}$ : Ada pengaruh yang signifikan persepsi guru tentang sumber belajar digital terhadap motivasi guru memanfaatkan sumber belajar digital.

Pengambilan keputusan berdasarkan probabilitas adalah sebagai berikut:

Jika Sig. > 0,05 maka Ho diterima Jika Sig. < 0,05 maka Ha ditolak, Ha diterima

Terlihat bahwa pada kolom Sig. untuk variabel persepsi guru tentang sumber belajar digital $\left(X_{2}\right)=0,000$ mempunyai angka signifikansi $<0,05$, dengan demikian Ha diterima atau dengan kata lain variabel variabel persepsi guru tentang sumber belajar digital $\left(X_{2}\right)$ signifikan mempengaruhi motivasi guru memanfaatkan sumber belajar digital.

Uji Hipotesis Simultan (Uji F)

Hipotesis yang dibangun adalah sebagai berikut:

Hipotesis Ketiga:

$\mathrm{Ho}_{3}$ : Tidak ada pengaruh yang signifikan persepsi guru tentang digital natives 
dan persepsi guru tentang sumber belajar digital terhadap motivasi guru memanfaatkan sumber belajar digital.

$\mathrm{Ha}_{3}$ : Ada pengaruh yang signifikan persepsi guru tentang digital natives dan persepsi guru tentang sumber belajar digital terhadap motivasi guru memanfaatkan sumber belajar digital. Pengambilan keputusan berdasarkan probabilitas adalah sebagai berikut:

Jika Sig. > 0,05 maka Ho diterima Jika Sig. < 0,05 maka Ha ditolak, Ha diterima

Dari uji Anova atau uji $\mathrm{F}$, didapat $F_{\text {hitung }}$ 35, 348 dengan tingkat signifikansi sebesar 0,000. Karena probabilitas (tingkat signifikansi) ini lebih kecil daripada 0,05 maka model regresi ini bisa dipakai untuk memprediksi motivasi guru memanfaatkan sumber belajar digital. Dengan kata lain, persepsi guru tentang digital natives dan persepsi guru tentang sumber belajar digital secara bersama-sama berpengaruh terhadap motivasi guru memanfaatkan sumber belajar digital.

\section{Koefisien Determinasi dan Korelasi}

Nilai Koefisien Determinasi atau $\mathrm{R}$ Square (R2) dari hasil pengolahan data adalah sebesar 0,521 atau 52,1\% (tabel model summary). Nilai tersebut memberikan gambaran bahwa sumbangan variabel bebas (persepsi guru tentang digital natives dan persepsi guru tentang sumber belajar digital) dalam pengaruhnya terhadap variabel terikat (motivasi guru memanfaatkan sumber belajar digital) adalah sebesar $52,1 \%$ dan sisanya sebesar $47,9 \%$ merupakan sumbangan variabel-variabel lain yang tidak diteliti (e). Nilai korelasi berganda (R) dari hasil pengolahan data adalah sebesar 0,722 atau $72,2 \%$. Nilai korelasi tersebut menggambarkan bahwa antara variabel bebas dengan variabel terikat mempunyai hubungan yang erat.

Pembahasan

Berdasarkan hasil analisis regresi dan uji hipotesis pertama dalam penelitian ini menunjukkan bahwa dengan nilai koe- fisien regresi sebesar 0, 764 dan nilai signifikansi 0,000, variabel persepsi guru tentang digital natives mempunyai pengaruh yang positif dan signifikan terhadap motivasi guru memanfaatkan sumber belajar digital. Hal ini berarti guru yang memiliki persepsi yang baik tentang digital natives akan memiliki motivasi yang tinggi untuk memanfaatkan sumber belajar digital. Demikian pula sebaliknya, jika persepsi guru tentang digital natives kurang baik maka motivasi guru memanfaatkan sumber-sumber belajar digital akan berkurang.

Hasil uji hipotesis kedua menunjukkan bahwa dengan nilai koefisien regresi sebesar 1, 079 dan nilai signifikansi 0,000, variabel persepsi guru tentang sumber belajar digital mempunyai pengaruh yang posi-tif dan signifikan terhadap motivasi guru memanfaatkan sumber belajar digital. Artinya, jika persepsi guru tentang sumber belajar digital baik maka berdampak pula pada tingginya motivasi guru memanfaatkan sumber-sumber belajar digital. Demikian pula sebaliknya, jika persepsi guru tentang sumber belajar digital kurang baik maka motivasi guru memanfaatkan sumber-sumber belajar digital akan berkurang.

Demikian pula hasil uji hipotesis ketiga menunjukkan persepsi guru tentang digital natives dan variabel persepsi guru tentang sumber belajar digital secara bersama-sama berpengaruh positif dan signifikan terhadap motivasi guru memanfaatkan sumber belajar digital dengan nilai $\mathrm{F}$ hitung 35,348 dan tingkat signifikansi sebesar 0,000 . Berpijak pada hasil penelitian tersebut dapat disimpulkan bahwa variabel persepsi guru tentang digital natives dan variabel persepsi guru tentang sumber belajar digital menjadi prediktor penting bagi motivasi guru memanfaatkan sumber belajar digital dalam penelitian ini.

\section{Simpulan dan Saran}

Simpulan

Berdasarkan hasil penelitian dan pembahasan dalam penelitian ini maka dapat ditarik kesimpulan sebagai berikut: 
Ada pengaruh yang positif dan signifikan persepsi guru tentang digital natives terhadap motivasi guru memanfaatkan sumber belajar digital dengan koefisien regresi sebesar 0,764 dan probabilitas (nilai sig) = 0,000. Ada pengaruh yang positif dan signifikan persepsi guru tentang sumber belajar digital terhadap motivasi guru memanfaatkan sumber belajar digital dengan koefisien regresi sebesar 1, 079 dan probabilitas (nilai sig) $=0,000$. Ada pengaruh yang positif dan signifikan secara bersamasama persepsi guru tentang digital natives dan persepsi guru tentang sumber belajar digital terhadap motivasi guru memanfaatkan sumber belajar digital dengan nilai $F_{\text {hitung }} 35,348$ dan probabilitas (nilai sig) $=$ 0,000 .

\section{Saran}

Berdasarkan hasil penelitian maka dapat disarankan beberapa hal sebagai berikut: Berkenaan dengan pengaruh positif dan signifikan persepsi tentang digital natives dan sumber belajar digital terhadap motivasi untuk memanfaatkan sumbersumber belajar digital penelitian ini menyarankan manajemen sekolah untuk menyiapkan situasi yang kondusif untuk untuk menunjang tumbuhnya persepsi yang baik dan motivasi yang tinggi memanfaatkan sumber-sumber belajar digital yang telah disediakan pihak sekolah maupun sumber-sumber belajar digital lainnya yang dapat diperoleh diluar sekolah untuk meningkatkan kualitas pembelajaran. Kepada para peneliti agar dapat melakukan pengembangan lanjutan dengan meneliti faktor-faktor lain yang mempengaruhi pemanfaatan sumber-sumber belajar baru (digital) di sekolah atau juga fakta-fakta lain yang menuntut adanya perubahan seiring dengan pemanfaatan teknologi dalam pembelajaran misalnya tentang peran guru.

\section{Daftar Pustaka}

AECT. (1986). Definisi teknologi pendidikan/satuan tugas definisi dan termino- logi. (Terjemahan Yusufhadi Miarso, dkk), Washington, DC: Associations for Educational Communications and Technology (AECT). (Buku asli diterbitkan tahun 1977).

Bingimlas, K. A. (2009). Barries to the succssesful integration of ICT in teaching and learning environments: a review of the literature. Eurasia Journal of Mathematics, Science and Technology Education, 5 (3), 235-245

British Educational Comunication and Technology Agency (BECTA) (2007). Harnessing technology schools survey. Diambil pada tanggal 4 Oktober 2013: http://dera.ioe.ac.uk/1554/1/bect a_2007_htssfindings_report.pdf

Gilakjani, A. P. (2013). Factors contributing to teachers' use of computer technology in the classroom. Universal Journal of Educational Research 1(3): 262-267.

Hill, J. R. \& Hannafin, M. J. (2001) Teaching and learning in digital environments: The Resurgence of ResourceBased Learning. ETR \& D, Vol. 49, No. 3, 37-52.

Huitt, W. (2011). Motivation to learn: An overview. Educational Psychology Interactive. Valdosta, GA: Valdosta State University. Diambil pada tanggal 27 Desember 2014 dari: http://www.edpsycinteractive.org /topics/motivation/motivate.html

Organisation for Economic Co-operation and Development (OECD). (2009). Beyond textbooks; digital learning resources as systemic innovation in the Noordic country. Diambil pada tanggal 29 September 2014 dari: http://browse.oecdbookshop.org/ oecd/pdfs/product/9609081e.pdf

Prensky, M. (2001a). Digital natives, digital immigrants. Dalam Horizon, 9 (5), 16. 
Reiser, A. R, Ely, P. D. (1997). The field of educational technology as reflected through Its definitions. Educational Technology Research and Development. Volume 45, Issue 3, 63-72.

Resnick, M. (2002). Rethinking learning in the digital age. Dalam G. Kirkman (Ed.) In The global information technology report: Readiness for the networked world (pp. 32-37). Oxford: Oxford University Press.

Roblyer, M.D. (2003). Integration educational technology into teaching. Colombus, Ohio.

Seels, B.B. and Richey, R.C. (1994). Teknologi pembelajaran definisi dan kawasannya. (Terjemahan Dewi S. Prawiradilaga, dkk) Whasington, DC: Associations for Educational Communications and Technology (AECT). (Buku asli diterbitkan tahun 1994).

Shulman, L. (1987). Knowledge and teaching: foundations of the new reform. Harvard Educational Review, Vol. 57, No. 1, 1 - 22.

VSO (2002). What makes teachers tick? A policy research report on teachers' motivation in developing countries. London: Voluntary Service Overseas (VSO). 